\title{
An Investigation of Physics Teachers' Multiple Representation Ability on Newton's Law Concept
}

\author{
Masrifah $^{1,2, a)}$, Agus Setiawan ${ }^{1, b)}$, Parlindungan Sinaga ${ }^{1, \mathrm{c})}$, Wawan Setiawan ${ }^{1, \mathrm{~d})}$ \\ ${ }^{1}$ Sekolah Pasca Sarjana, Universitas Pendidikan Indonesia, Jl. Dr. Setiabudhi No. 229, Bandung \\ 40154, Indonesia \\ ${ }^{2}$ Program Studi Pendidikan Fisika, Universitas Khairun Ternate, Jl. Bandara Baabullah, Kota \\ Ternate, 97728, Indonesia \\ a)masrifah@student.upi.edu, b)agus_setiawan@upi.edu, ${ }^{\mathrm{c}}$ psinaga@upi.edu, ${ }^{\mathrm{d})}$ wawans@upi.edu
}

\begin{abstract}
The ability of the teacher to represent a concept using various types of representation is a critical competency. Teachers who have limited multiple representation abilities will not be able to provide a holistic and appropriate learning experience because students have different abilities in constructing their knowledge. This study aims to determine the multiple representation ability of Physics teacher by using instruments to test multiple representations on the topic of Newton's law consisting of text representations, images, pictorial diagrams, tables, graphs, and mathematical equations. The subjects in this study were 30 high school Physics teachers in North Maluku who were determined based on the purposive sampling technique. Data on multiple teacher representation abilities were analyzed using descriptive statistics. The results of the data analysis showed that the multi-representation ability of high school physics teachers in Newton's law concept was in the medium category $(55.7 \%)$ with the highest achievement occurring in the type of mathematical representation and the lowest in the pictorial diagram representation types for both female and male teachers. Besides, based on data implemented using SPSS 2.0, it can be concluded that there are no significant differences with the ability of teacher's multirepresentation based on gender and teacher's teaching experience.
\end{abstract}

Keywords: multiple representations, pictorial diagrams, table representations, graphs

\section{INTRODUCTION}

Physics, which is part of science, requires understanding and ability to represent a concept in different ways (Gunel et al. 2006). According to (Hestenes 1997) that a good indicator of conceptual understanding is characterized by the ability to recognize and manipulate concepts in various representations. Therefore, the multiple representations approach is effective in increasing conceptual understanding (Van Heuvelen 1991a). This opinion is reinforced by the results of research, which states that the multi-representation approach to the concept of mechanics can build a deep and coherent understanding of concepts (Wong 2011).

Through multiple representations, the same concept can be explained by various types of representation modes (Ainsworth 1999). Multiple representations can also be interpreted as a way to represent the same concept in different formats, including verbal, mathematical, pictures, and graphics. Correspondingly, Waldrip, Prain, and Sellings (2008) state that the presence of multiple representations can be explicitly grouped, namely, knowledge of images, tables, graphs, mathematical, and diagrams. The choice of the form of representation to be used depends on the nature of the information represented and must be provided. Besides, the choice of the mode of representation is largely 
determined by the information that will be conveyed to the reader (Etkina et al. 2010). Some forms of representation that are widely used in physics learning include verbal, diagrams (vectors, motion maps, and path diagrams), graphs, and mathematics (Van Heuvelen 1991b).

Multiple representations represent the role of helping students in developing a better understanding because a concept presented using multiple representations can increase deep understanding so that students can build a complete understanding of the related concepts. Multiple representations enable learners to see complex ideas in a way and then to apply these complex ideas to learning effectively. This was reinforced by the results of research, which stated that content representation had an impact on students' cognition, problem-solving abilities, and the ability to express understanding to others (Bezemer and Kress 2008).

Physics teachers must know and realize that their students have diverse characteristics, both social, economic, ethnic background, and also their ability to understand the concepts being taught. Related to this, the teacher must be able to choose and use various types of representation mode to represent a concept because one type of representation mode that is considered most appropriate by the teacher may not necessarily be understood by all students. In the learning process in class, a teacher must be able to use a different mode of representation when he finds some students unable to understand the mode of representation used. These actions need to be taken so that students who initially did not understand become understood. Therefore, the teacher must have skills in making the concept of multiple representations. The ability to represent a concept using various modes of representation is a very important competency possessed by a teacher so that it can help overcome the difficulties of students in understanding the concepts of Physics being taught.

This study aims to identify the multiple representations abilities of Physics teachers on Newton's law concepts. Differences in the abilities of the physics teachers' multiple representations will also be identified based on their gender and teaching experience. The results of this study can be used as a reference in efforts to improve the quality of physics learning and develop teacher's pedagogical and professional competencies.

\section{METHODS}

The research method used is a descriptive research method in which the researcher tries to photograph the phenomena and events that occur and then describe them as they are (Sugiyono 2013). While participants involved in this study, namely 30 high school physics teachers consisting of 13 men and 17 women with teaching experience between 2-10 years.

The instrument used to identify the ability of the physics teacher's multiple representations was a multiple representations test problem on Newton's law concepts in the form of essays. The number of questions consisted of 6 questions ( 1 item of text representation, 1 item of picture representation, 1 item of pictorial diagram representation, 1 item of table representation, 1 item of graph representation, and 1 item of mathematical equation representation). A content validity test was conducted by three expert judgments to determine the level of validity of the instruments used. In the scoring process, rubric Physics Education Research (PER) is used in relation to scoring the ability to represent information in various ways developed by Etkina et al. (2006). The rubric uses scores ranging from 0 - 3, where 0 is for those who do not represent or do not work on problems (missing), 1 for inadequate representations, 2 for incomplete or inaccurate representations that require improvement (need some improvement), and 3 for adequate and correct representations.

Data analysis of the physics teacher's multiple representations ability was performed using descriptive statistics in the form of percentages. Furthermore, the data is categorized based on the capability category guidelines, according to Riduwan (2009). Besides, the Mann Whitney test with SPSS 20.0 is used to analyze differences in the physics teacher's multiple representations ability based on gender, and teaching experience because the research sample is classified as a small sample. 


\section{RESULT AND DISCUSSION}

\section{The Ability of Physics Teacher's multiple representations}

Data on the ability of multiple representations of high school physics teachers on Newton's law concept is generally seen in FIGURE 1.

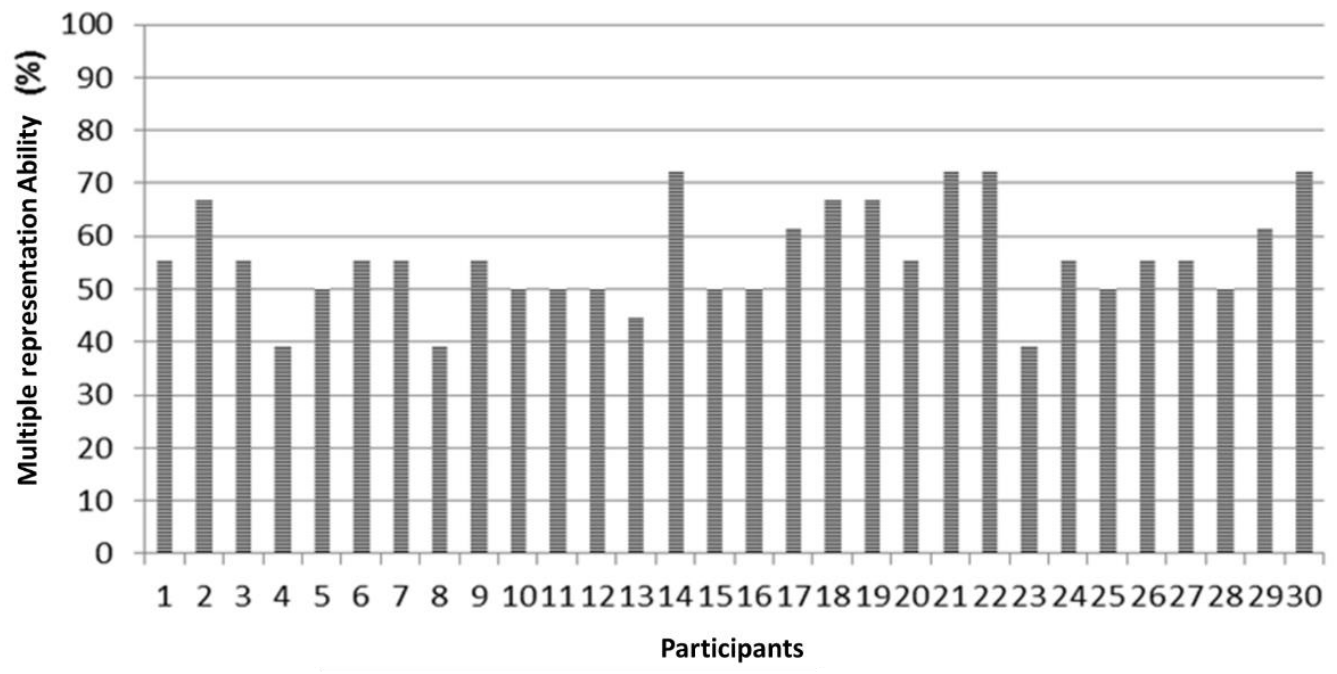

FIGURE 1. The ability of multiple representations of high school physics teachers in general.

Based on FIGURE 1, the average percentage of the ability of multiple representations of high school physics teachers on Newton's law concept, in general, is $55.7 \%$ in the medium category.

However, the results of the study also showed that the ability of teachers to represent Newton's law concepts was still inadequate (Inadequate). This is evidenced by the still many teachers who get a score of 1 on each type of representation. The highest score achieved by the teacher is 13 , and the lowest score is 9 from the maximum score of 18. The result is very ironic considering the importance of multiple-representations ability for Physics teachers because to teach Physics effectively. The teacher must understand the use of representation in explaining a Physics concept and be able to translate a representation of the concept from one form to another (Ainsworth 1999). Multiple representations in teaching can provide space for teachers to utilize various representations in explaining abstract physics phenomena by transforming them into a visual representation.

Multiple representations are very supportive for use in conceptual learning, such as Physics, because multiple representations place greater emphasis on understanding concepts and qualitative reasoning in learning (Dufresne, Grace, \& Leonard 1997). This is reinforced by the opinion Kohl, Rosegrant, \& Finkelstein (2007) states that multiple representations learning can be considered as the key to learning physics. A multiple representations approach to learning and teaching has the potential to produce an effective learning process. Through diverse representations will create an atmosphere of learning with the active role of all potentials of students, activating students' learning abilities, both minds-on and hands-on, so that learning is more meaningful than before. This is supported by the research results of Siswanto, Susantini, \& Jatmiko (2016), which state that for the success of Physics learning, students need to understand the multiple representations of Physics concepts correctly and adequately. Furthermore, according to the research results of Widianingtiyas, Siswoyo, \& Bakri (2015), physics learning using multi-representation has a positive influence on students' cognitive abilities because it can build student understanding by providing complete information from various forms of representation presented. Other research results state that learning physics using multi-representation can improve student achievement and scientific consistency (Sari, Feranie, \& Karim 2015). 


\section{The ability for each type of representation}

The multiple representations ability of high school physics teachers on Newton's law concept analyzed in this study is divided into six types of representations, namely text, images, pictorial diagrams, mathematical equations, tables, and graphs. Data from the analysis of each type of representation is presented in FIGURE 2.

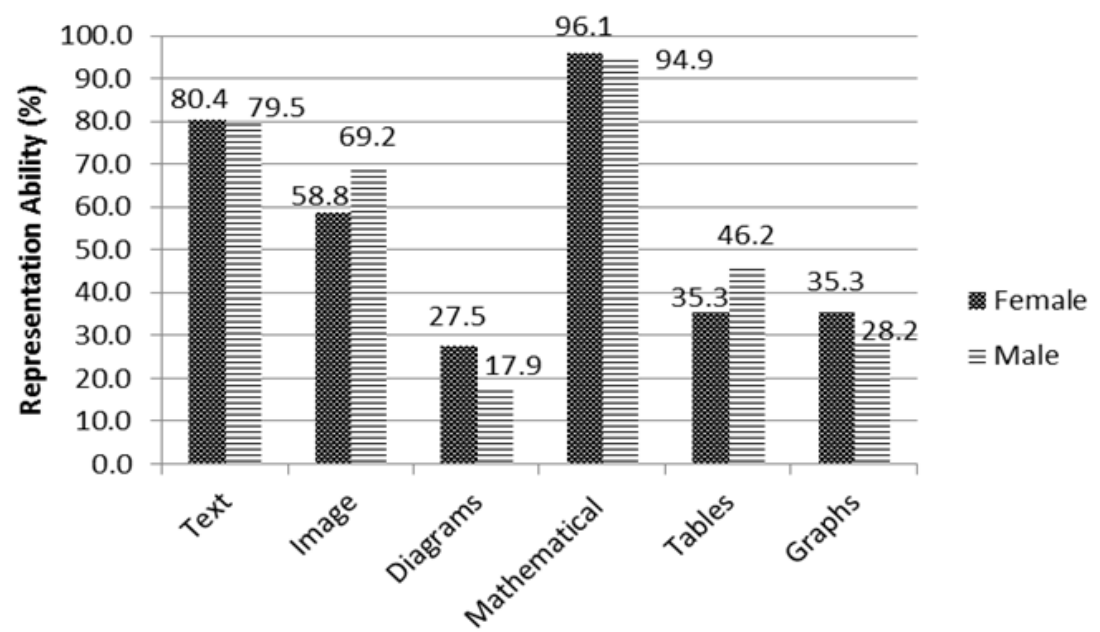

FIGURE 2. The ability of multiple representations of high school physics teachers in each type of representation

The findings of the research based on FIGURE 2 show that the highest achievement of the ability of the physics teacher's representation of Newton's law concept occurs in the type of mathematical representation. This achievement occurred in both female and male teachers with a large percentage of each, namely $96.1 \%$ and $94.9 \%$. That is because almost all teachers are accustomed to using mathematical equations in teaching the concept of Newton's law to their students in the learning process in class so that this type of representation is familiar to them.

While the lowest achievement occurs in the type of pictorial diagram representation both female and male teachers. One of the factors that causes the low ability of teachers to represent concepts in the form of pictorial diagrams is the lack of knowledge and understanding of teachers about pictorial diagrams because most Physics teachers do not yet know what is meant by pictorial diagrams so that they have difficulty in working on given problems. This is evidenced by the acquisition of an average percentage value, namely $27.5 \%$ of a female teacher and $17.9 \%$ of male teachers which can be categorized as less based on the five scale conversion guidelines. The teacher's initial understanding of the pictorial diagram shows that the teacher considers the pictorial diagram to be the same as the bar diagram while the correct definition of pictorial diagrams is a diagram showing the initial to the final state of the movement of an object.

Based on the results of the analysis also seen that the text representation and mathematical equations are in the very high category and the image representation in the medium category. Whereas the other three types of representations are in the low category, namely the representation of tables, graphs and pictorial diagrams. While teachers must have the ability to make and use all types of representations in learning because the various forms of representation are interrelated and reinforce each other's explanation of physics concepts, according to Angel et al. (2008) many physical phenomena in everyday life are abstract, so visual explanations such as text or images are needed. The use of multirepresentation by making connections between types of representations can help in understanding and solving physics problems.

Besides, one type of representation that is considered most appropriate by the teacher may not be understood by all students. In the learning process in the classroom, a teacher must be able to use different types of representations when some students find it difficult to understand the type of representation used. According to Suhandi (2012), if the concept is only emphasized in one or two forms of representation, it will only benefit for some students. For example, presentation of concepts that are only in the form of verbal representations; students who are more prominent in their spatial 
ability will find it difficult to understand the concepts presented. Therefore, the teacher must have skills in making various types of concept representations. The ability to represent a concept using various modes of representation is a very important competency possessed by a teacher in order to create meaningful learning for students. Therefore, teachers need to improve their representation abilities for all kind of representations. This multi-representation skill can be trained on the teacher through training activities or routine meetings in schools such as the Physics teacher MGMP.

\section{The Ability of Multiple representations of Physics Teachers Based on Gender}

The Mann Whitney test was conducted to compare the multiple representations abilities of high school physics teachers on Newton's law concepts for male and female teachers. Participants in this study consisted of 13 men and 17 women. The results of the analysis are presented in TABLE 1, which shows that there are no significant differences in multiple representations ability between male and female teachers in all types of representation. It shows that gender does not affect the multiple representations ability of physics teachers on Newton's law concepts.

TABLE 1. The Ability of Multiple-representations of Physics Teachers

\begin{tabular}{lccccccc}
\hline \multicolumn{2}{c}{ Male } & \multicolumn{2}{c}{ Female } \\
& $\begin{array}{c}\text { Mean } \\
\text { rank }\end{array}$ & $\begin{array}{c}\text { Sum of } \\
\text { ranks }\end{array}$ & $\begin{array}{c}\text { Mean } \\
\text { rank }\end{array}$ & $\begin{array}{c}\text { Sum of } \\
\text { ranks }\end{array}$ & U & p & Result \\
\hline Text & 15.35 & 199.50 & 15.62 & 265.50 & 108.500 & 0.925 & No difference \\
Images & 17.31 & 225.00 & 14.12 & 240.00 & 87.000 & 0.292 & No difference \\
Pictorial Diagram & 12.96 & 168.50 & 17.44 & 296.50 & 77.500 & 0.101 & No difference \\
Mathematics & 15.77 & 205.00 & 15.29 & 260.00 & 107.000 & 0.778 & No difference \\
Table & 16.73 & 217.50 & 14.56 & 247.50 & 94.500 & 0.466 & No difference \\
Graph & 14.35 & 186.50 & 16.38 & 278.50 & 95.500 & 0.368 & No difference \\
\hline
\end{tabular}

\section{The Ability of Physics Teachers' multiple representations based on Teaching Experience}

The results of the analysis using Mann Whitney conducted to compare the multiple representations abilities of high school physics teachers on Newton's law concept based on the teacher's Teaching Experience can be seen in TABLE 2. The results show that there is no significant difference in multiple representations of ability in all types of representations studied. It shows that the teacher's Teaching Experience does not affect the multiple representations ability of Physics teachers on Newton's law concepts because both teachers who have been teaching for a long time and who have only recently taught generally tend to only use the same types of representations, namely text, images, and mathematical equations.

TABLE 2. The Ability of Physics Teachers' multiple representations based on Teaching Experience

\begin{tabular}{lccccccc}
\hline \multicolumn{7}{c}{$\begin{array}{c}\text { More than 6 } \\
\text { years }\end{array}$} & \multicolumn{2}{c}{ Less than 6 } \\
& $\begin{array}{c}\text { Mean } \\
\text { rank }\end{array}$ & $\begin{array}{c}\text { Sum of } \\
\text { ranks }\end{array}$ & $\begin{array}{c}\text { Mean } \\
\text { rank }\end{array}$ & $\begin{array}{c}\text { Sum of } \\
\text { ranks }\end{array}$ & U & P & Result \\
\hline Text & 16.00 & 256.00 & 14.93 & 209.00 & 104.000 & 0.710 & No difference \\
Images & 15.91 & 254.50 & 15.04 & 210.50 & 105.500 & 0.772 & No difference \\
Pictorial Diagram & 16.09 & 257.50 & 14.82 & 207.50 & 102.500 & 0.639 & No difference \\
Mathematics & 15.19 & 243.00 & 15.86 & 222.00 & 107.000 & 0.690 & No difference \\
Table & 15.19 & 243.50 & 15.86 & 222.00 & 107.000 & 0.821 & No difference \\
Graph & 16.38 & 262.00 & 14.50 & 203.00 & 98.000 & 0.404 & No difference \\
\hline
\end{tabular}




\section{CONCLUSION}

The multi-representation ability of high school physics teachers in Newton's legal concepts, in general, is in the medium category, with an average percentage of $55.7 \%$. While the highest achievement of the ability of multi-representation of Physics teachers in Newton's legal concepts occurs in the type of mathematical representation and the lowest occurs in the type of pictorial diagram representation, both in female teachers and male teachers. The results of the analysis using Mann Whitney showed that the ability of multi-representation between female and male teachers was not significantly different. Likewise, based on his work experience, the ability to represent Newton's concept of Newton's law does not show any significant difference between female and male teachers. The research result that has been presented indicating that the ability of Physics teachers needs to be improved. The efforts to improve the ability of multi-representation physics teachers can be made through specialized training such as MGMP, workshops, or in other forms that provide multirepresentation based physics learning.

\section{ACKNOWLEDGMENTS}

The author would like to acknowledge the Ministry of Research and Technology of Higher Education as the research funders, to the Higher Education Institutions and Education Unit Levels involved, as well as those who have helped carry out this research.

\section{REFERENCES}

Ainsworth, S 1999, 'The functions of multiple representations', Computer \& Education, vol. 33, pp.131-52.

Angel, C, Kind, P, Henriksen, E, \& Guttersrud, Q 2008, 'An empirical-mathematical modeling approach to upper secondary physics', Physics Education, vol. 43, no. 3, pp.256-64.

Bezemer, J \& Kress, G 2008, 'Writing in Multimodal Texts: A Social Semiotic Account of Designs for Learning', Writing Communication, vol. 25, no. 2, pp. 166-95.

Dufresne, RJ, Grace, WJ, \& Leonard, WJ 1997, 'Solving physics problems with multiple representations', Phys. Teach, vol. 35. pp. 270-5.

Etkina, E 2006, 'Scientific Abilities and Their Assessment, Physical Review Special Topics', Physics Education Research, vol. 2, p. 020103.

Etkina, Eugenia 2010, 'Rubric Scientific Ability to Represent Information in Multiple Way', Rutgers, The State University of New Jersey GSE, 10 Seminary Place, New Brunswick NJ, viewed 13 March 2014.

Gunel, M, Hand, B, \& Prain, V 2006, 'Writing for learning in science: A secondary analysis of six studies', International Journal of Science and Mathematics Education, vol. 5, pp. 615-37.

Hestenes, D 1997, 'Modeling methodology for physics teachers, in the changing role of physics departments in modern universities', Proceedings of the International Conference on Undergraduate Physics Education, p. 935.

Kohl, P, Rosegrant, D, Finkelstein, ND 2007, 'Strongly and weakly directed approaches to teaching multiple representation use in physics', Physics Education Research, vol. 3, pp.1-10.

Riduwan 2009, Pengantar Statistika untuk Penelitian Pendidikan, Sosial, Ekonomi, Komunikasi, dan Bisnis, Alfabeta, Bandung.

Sari, AP, Feranie, S, \& Karim, S 2015, 'Penerapan Pembelajaran Berbasis Masalah dengan Pendekatan Multirepresentasi untuk Meningkatkan Prestasi Belajar dan Konsistensi Ilmiah Berbasis Multirepresentasi pada Materi Elastisitas', Jurnal Penelitian \& Pengembangan Pendidikan Fisika, vol. 1, no. 2, pp. 45-50. 
Siswanto, J, Susantini, E, \& Jatmiko, B 2016, 'Kepraktisan Model Pembelajaran Investigasi Based Multiple Representation (IBMR) dalam pembelajaran Fisika', Journal Penelitian Pembelajaran Fisika, vol. 7, pp. 127-31.

Sugiyono 2013, Metode Penelitian Pendidikan (Pendekatan Kuantitatif, Kualitatif dan R\&D), Alfabeta, Bandung.

Suhandi, A 2012, 'Pendekatan multi representasi dalam pembelajaran usaha-energi dan dampak terhadap pemahaman konsep mahasiswa', Jurnal Pendidikan Fisika Indonesia, vol. 8, pp. 1-7.

Van Heuvelen, A 1991a, 'Learning to think like a physicist: A review of research-based instructional strategies', Am. J. Phys. vol. 59, no. 10, pp. 891-7.

Van Heuvelen, A 1991b, 'Overview, Case Study Physics', Am. J.Phys, vol. 59, no. 10, pp. 898-907.

Waldrip, B, Prain, V, Sellings, P 2008, 'Explaining Newton's laws of motion: using student reasoning through representations to develop conceptual understanding', Instr Sci, vol. 41, pp. 165-89.

Widianingtiyas, L, Siswoyo, S, Bakri, F 2015, 'Pengaruh pendekatan multi representasi dalam pembelajaran fisika terhadap kemampuan kognitif siswa SMA', Jurnal Penelitian \& Pengembangan Pendidikan Fisika, vol. 1, no. 1, pp. 31-7.

Wong D 2011, 'Learning with multiple representations: an example of a revision lesson in mechanic', Phys.Educ, vol. 46, no. 2, pp.178-186. 
